\title{
FOREIGN INVESTMENTS AND FISCAL STIMULATION IN UZBEKISTAN
}

Nargiza Yakubova ${ }^{1}$

\begin{abstract}
This article analyzes the trends in foreign capital inflows into selected CIS countries, using a documented analysis. The study revealed that despite improved macroeconomic stability and economic growth capital inflow in CIS countries is modest, reflecting a weak overall investment climate in the region. The study results show that private capital inflows into these countries consist mainly of direct investments, and concentrate in the few countries with big oil reserves. Lack of protection for property rights, with threats from corruption, crime, and excessive regulation, was the significant investment impediment cited most frequently in the research. Despite Uzbekistan shows strong growth comparing a weak performance in the broader Europe and Central Asia region, the level of efficiency of using the incentives still remaining low. According the results of the study unconditional and irrevocable tax and customs exemptions are the main reasons for the low efficiency of the incentives. The paper subsequently suggests that fiscal stimulus are only marginally efficient in the absence of effective monetary, exchange-rate, and industrial policies.
\end{abstract}

UDC Classification: 336.2, 336.5, DOI: http://dx.doi.org/10.12955/cbup.v3.607

Keywords: Investments, tax, incentives, Uzbekistan, effectiveness

\section{Introduction}

Foreign investments play an important role in filling the gap between domestic savings and the high levels of investment needs in the Commonwealth of Independent States (CIS) ${ }^{2}$ (Shiells, 2003). Foreign investments mostly involve the creation of new joint firms or expansion of existing branches in these countries, the study revealed (see among others, Borensztein, De Gregorio, \& Lee, 1998; Vandycke, 2003; Tsamenyi \& Tauringana, 2004; Peimani, 2009).

According to De Broeck \& Koen (2000), investments in the CIS countries contracted sharply after the breakup of the Soviet Union. The comparative study shows a huge difference in the levels of inflow per capita of cumulative-net foreign direct investment (FDI) between some of the transitioning economies of Central and Eastern Europe and the Baltic States $(\mathrm{CEB})^{3}$, and the CIS countries. The study reveals the average annual levels of net FDI inflows, relative to gross domestic product (GDP), also fall short of levels in the CEB countries (Figure 1).

The study of the effectiveness of fiscal stimulation in Uzbekistan suggests that these incentives were only marginally efficient (Gaybullaev, 2011).

This paper aims to provide insights into the investment environment, and analyze the factors influencing these. The study is important because there is a high rate of failure for foreign investments in the region (Colin, 1998). The findings of this study will benefit both local and foreign investors who are interested in investment opportunities in the region including Uzbekistan.

\section{Investment climate in selected CIS countries}

Broadman (2002) reveals that the investment climate in the CIS countries is characterized by a complex set of relationships within the dominating state-enterprise sector, as well as the government's interference in private sector activity ${ }^{4}$. Moreover, government overregulation in the form of business

\footnotetext{
${ }^{1}$ Nargiza Yakubova, Tashkent Institute of Finance, Uzbekistan, yakubovanargiza@mail.ru

2 These are Armenia, Azerbaijan, Belarus, Georgia, Kazakhstan, the Kyrgyz Republic, Moldova, Russia, Tajikistan, Turkmenistan, Ukraine, and Uzbekistan.

${ }^{3}$ According to the European Bank for Reconstruction and Development's (EBRD's) CEB countries are Croatia, the Czech Republic, Estonia, Hungary, Latvia, Lithuania, Poland, the Slovak Republic, and Slovenia.

${ }^{4}$ Vandycke (2003) describes deficiencies in the environment for private sector development in the CIS-7 countries (Armenia, Azerbaijan, Georgia, the Kyrgyz Republic, Moldova, Tajikistan, and Uzbekistan).
} 
licensing, inspections, and certification, combined with low civil service salaries, and more generally, weak public administration, provide incentives for rent seeking by public officials. In addition, barriers to entry, impediments to competition, ineffective bankruptcy procedures, and weak corporate governance, allow inefficient incumbent enterprises to remain in operation. The analysis of the quality of "investment climate", which depends on both policies and institutions in the CIS countries, is a large concern, even for countries such as Azerbaijan, Kazakhstan, and Russia with high levels of oil resources, according to the International Monetary Fund (IMF) report (Shiells, 2003).

To test the effectiveness of tax incentives in this study, we used the IMF survey to identify the factors that had influenced, either favorably or adversely, a country's investment climate. The study, based on the IMF survey (Shiells, 2003), revealed that the investment climate depends on a wide array of factors. These include burdensome taxation, widespread corruption, poor governance, weak legal and regulatory frameworks (including property rights violations), pervasive state involvement in the economy, and the need to follow through with structural reform programs.

Figure 1: Commonwealth of Independent States (CIS), Central and Eastern Europe, and the Baltic States (CEB): Net FDI Inflows, 1999-2001

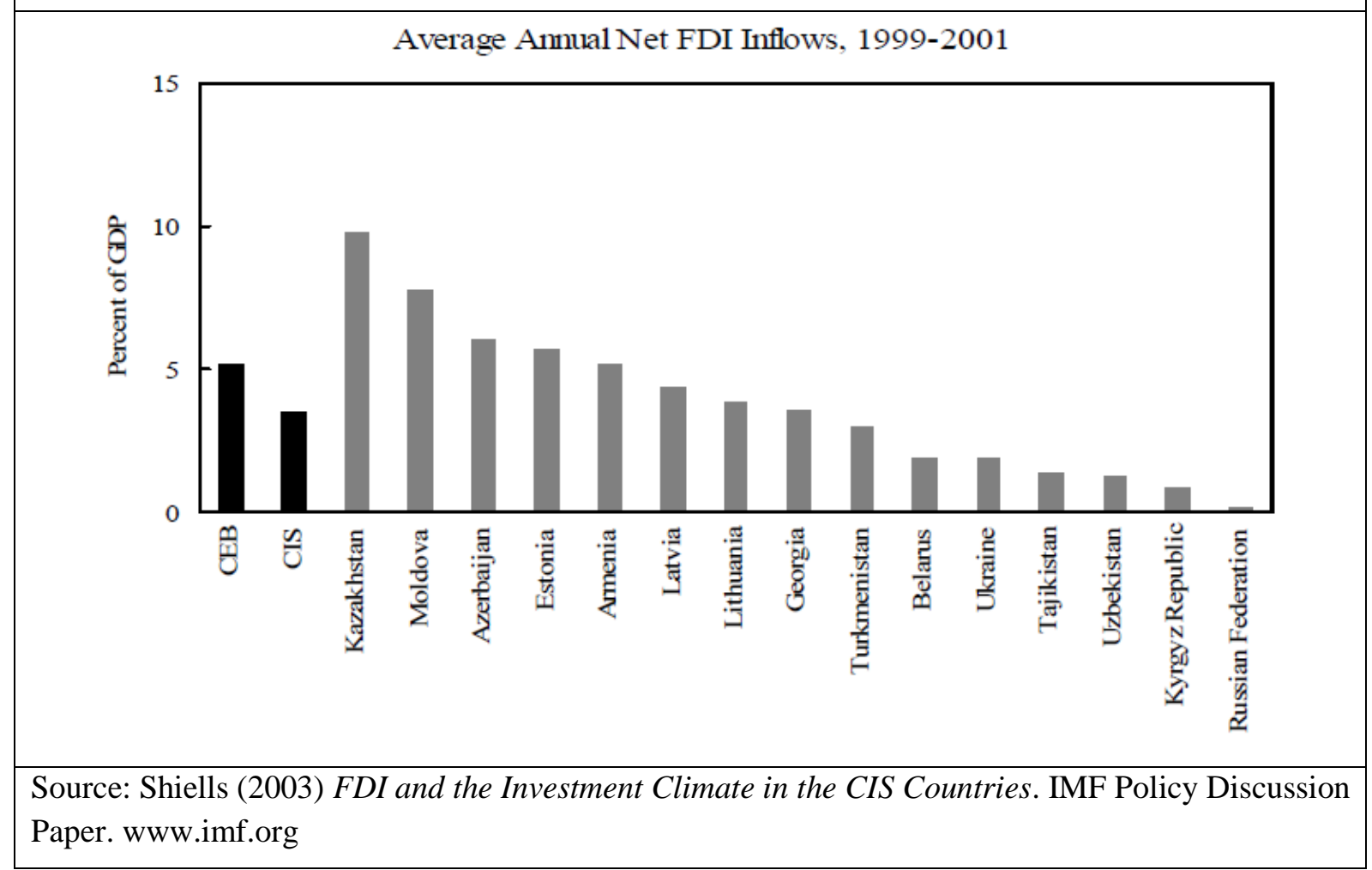

As noted above, international comparisons indicate that cumulative net FDI inflows per capita remain very low in the CIS countries, compared to the CEB countries. This is despite progress in achieving macroeconomic stability and the countries attaining relatively high growth rates. Foreign direct investment, into energy-exporting countries (Azerbaijan, Kazakhstan, Russia, and Turkmenistan), has generally been limited to the energy sector. For instance, almost $60 \%$ all foreign investments in Uzbekistan is in oil and gas sector, according to data provided by the Ministry for Foreign Economic Relations, Investments and Trade of the Republic of Uzbekistan (2014). The energy sector is often subject to a separate tax regime, which may alter investment incentives in these countries. In practice, the multinational energy companies have much expertise in dealing with poor governance, including corrupt regimes. However, it is useful to distinguish the energy-importing countries that have pursued market-oriented economic reforms (Armenia, Georgia, the Kyrgyz Republic, Moldova, Tajikistan, and Ukraine) from other energy importers (Belarus and Uzbekistan). 
Lankes \& Venables (1996) and EBRD (1994) argue that direct investment into the CIS countries involves more "resource seeking," whereas in more advanced countries this investment is predominantly "efficiency seeking".

Taxes ranked fourth place (out of eight) as an impediment to investments, based on a comparison of the responses of IMF country teams with the results of other regions. The 1997 World Development Report gave this as the ranking of obstacles for doing business. According to the survey for the 12 CIS countries, corruption and regulation were cited as impediments in the responses of teams for 10 countries; crime such as theft, financing, and policy instability were cited for five; taxes and poor infrastructure were cited for three; while inflation was not cited for any of the countries.

Prior to recent reforms (including of the income and profits taxes), the tax regime was cited as the greatest impediment to investment and entrepreneurship in Russia, according to Owen and Robinson (2003). Despite a liberal foreign investment policy in Georgia (including unlimited tax-free repatriation of capital and profits), tax officials often demanded bribes and advancement of tax payments from foreign companies. The research conducted by Elborgh-Woytek \& Lewis (2002) summarizes findings of the survey of foreign investors in 2000 (International Center for Policy Studies in Kyiv) and survey in 2002 (the American Chamber of Commerce) which shows that a high tax burden and the impossibility of land pledges were among of the main deterrents adversely affected the investment climate in Ukraine.

The current weak transparency system of privileges and tax exemptions has reportedly slowed down of investment inflow in Uzbekistan, according to the IMF country team report (Shiells, 2003).

In summary, tax incentives in CIS countries consist of organizing the Special Economic Zones (SEZ), incentives for R\&D and similar (Kazakhstan, Russia), and tax holidays (Uzbekistan, Kyrgyzstan, Tajikistan). However, among the studied CIS countries, tax stimuli are very limited in Turkmenistan. The Customs Union, launched in 2010 with elimination of customs duties and harmonization of VAT (Russia, Kazakhstan, and Belarus), are the most recent developments in the stimulus program. Another project involves the Common Economic Space of 2012, with fundamental freedoms, and aims to use tax incentives like SEZ to affect the course of FDI (Balco, 2013).

\section{Economic developments and fiscal incentives in Uzbekistan}

According to the World Bank report (2014), Uzbekistan shows strong growth despite a weak performance in the broader Europe and Central Asia region. In 2013, its GDP expanded by 8.0\%, while output averaged 8.4\% per annum between 2008 and 2013, making Uzbekistan one of the fastest growing economies in the middle-income country grouping (Figure 2).

The government implemented a US $\$ 47$ billion public investment program for 2011-15 to compensate for the external market volatility and a declining commodity prices. According to official data, the total investment to GDP in 2013 was $23.2 \%$, with about 20\% of GDP from nongovernment entities. The FDI, however, declined from 3.6\% of GDP in 2011 to an estimated 1.2\% in both 2012 and 2013. At the same time, rising wages (by $17 \%$ in nominal terms) helped to drive private consumption.

The state policy for industrialization is contributing to changes in the structure of Uzbekistan's economy. While services continued to dominate the economy in 2013, the share from industry increased by around $10 \%$ over the past decade to reach a $24.2 \%$ share of GDP (Table 1).

According to the regional forecast (IMF, 2014), the growth in Central Asia and Caucasus will slow to $1 \%$ of GDP because of the Russian economic turmoil (caused by Western sanctions and the fall of oil price), which influences foreign trade, investments, and remittances. 
CBU INTERNATIONAL CONFERENCE ON INNOVATION, TECHNOLOGY TRANSFER AND EDUCATION

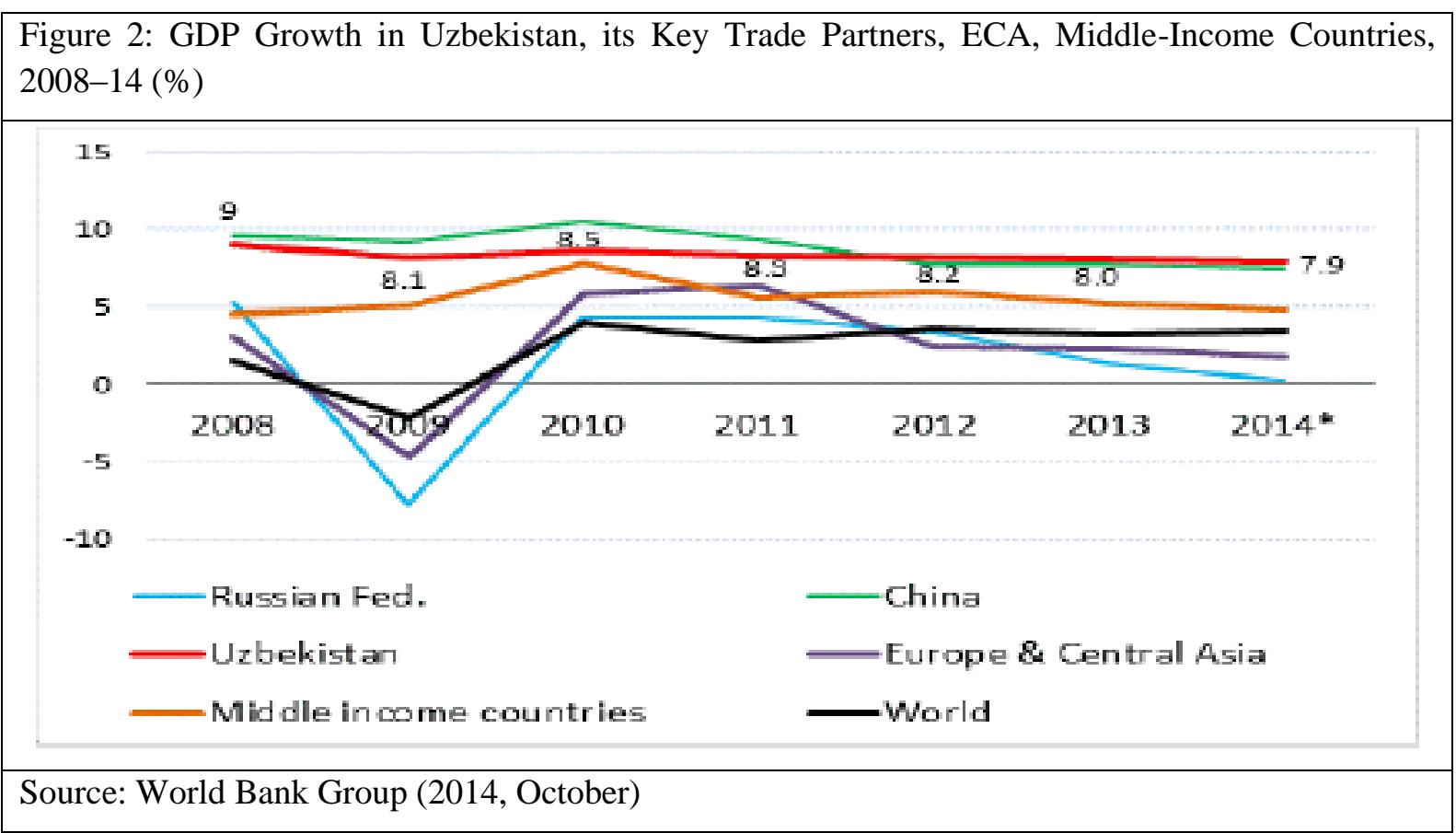

Table 1: Uzbekistan: key economic indicators, 2011-2014

\begin{tabular}{|l|r|r|r|r|}
\hline & \multicolumn{1}{|c|}{$\mathbf{2 0 1 1}$} & \multicolumn{1}{|c|}{$\mathbf{2 0 1 2}$} & \multicolumn{1}{|c|}{$\mathbf{2 0 1 3 e}$} & \multicolumn{1}{|c|}{$\mathbf{2 0 1 4 f}$} \\
\hline GDP growth (\%) & 8.3 & 8.2 & 8.0 & 7.9 \\
\hline GDP per capita, current (US\$) & 1,377 & 1,545 & 1,719 & 1.878 \\
\hline Population - mid-year (million) & 29.3 & 29.8 & 30.2 & 30.7 \\
\hline $\begin{array}{l}\text { Gross investment in fixed capital, } \\
\text { (\% of GDP) }\end{array}$ & 23.1 & 22.8 & 23.3 & 24.3 \\
\hline $\begin{array}{l}\text { Inflation - official consumption price } \\
\text { index (\% change) }\end{array}$ & 7.3 & 7.0 & 6.8 & 6.7 \\
\hline Inflation - GDP deflator (\% change) & 15.1 & 15.0 & 13.9 & 11.9 \\
\hline Current account balance (\% of GDP) & 5.8 & 1.2 & 2.5 & 2.2 \\
\hline Fiscal balance (\% of GDP) & 8.8 & 4.7 & 2.1 & $3.5 \mathrm{a} /$ \\
\hline Net FDI net (\% of GDP) & 3.6 & 1.2 & 1.2 & 1.3 \\
\hline Net labor remittances net (\% of GDP) & 5.9 & 6.4 & 6.4 & 6.0 \\
\hline External debt (\% of GDP) & 18.6 & 17.3 & 18.7 & 19.6 \\
\hline
\end{tabular}

Notes: $\mathrm{e}=$ preliminary or estimate; $\mathrm{f}=$ Bank staff forecast; a/: A one-off transfer of international reserves into the FRD (as was made in 2008, 2011, and 2012), combined with higher FRD revenues, is expected to help push up the consolidated fiscal balance in 2014.

Source: World Bank Group (2014, October)

The analysis of foreign trade shows that gas, cars, and food exports have declined, while exports of cotton, fertilizers, and services to Russia, have increased. However, the Uzbek firms were able to move the declining export items from Russia to China, and managed to increase exports of textile, gold, and other goods, according to the World Bank (2014). 
According to a tax incentives strategy, the tax burden, as total of tax revenues, has been falling as a share of GDP. The analysis shows that taxes fell from 26.2\% of GDP in 2000 to $21.5 \%$ of GDP in 2008, and then to an estimated 20.3\% of GDP in 2013 (Figure 3). These reductions were compensated by rising indirect tax rates (such as taxes on property, water use, royalties on mineral deposits, consumption of gasoline and alcohol, excises on some imported foodstuffs, and the like.). The Aggregate Tax Burden decreased by almost three times.

Uzbekistan offers a wide range of fiscal incentives, to help companies replace obsolete equipment, and otherwise modernize production. It has lifted many tax obligations including income tax, property tax, the single tax for small enterprises, and taxes on technology imports. In 2011, the total value of the tax relief amounted to 847.9 billion soums, or 1.1\% of GDP (Gaybullaev, 2011). The effectiveness of the modernization efforts relate to the country's high rates of investment and economic growth. During 2007 to 2011, total investment exceeded 70.3 trillion soums or US $\$ 40.8$ billion (in 2011 prices). Average investment levels grew annually by $21 \%$ during the period, compared with an average annual increase of 4.4\% from 2000 to 2005 (Gaybullaev, 2011).

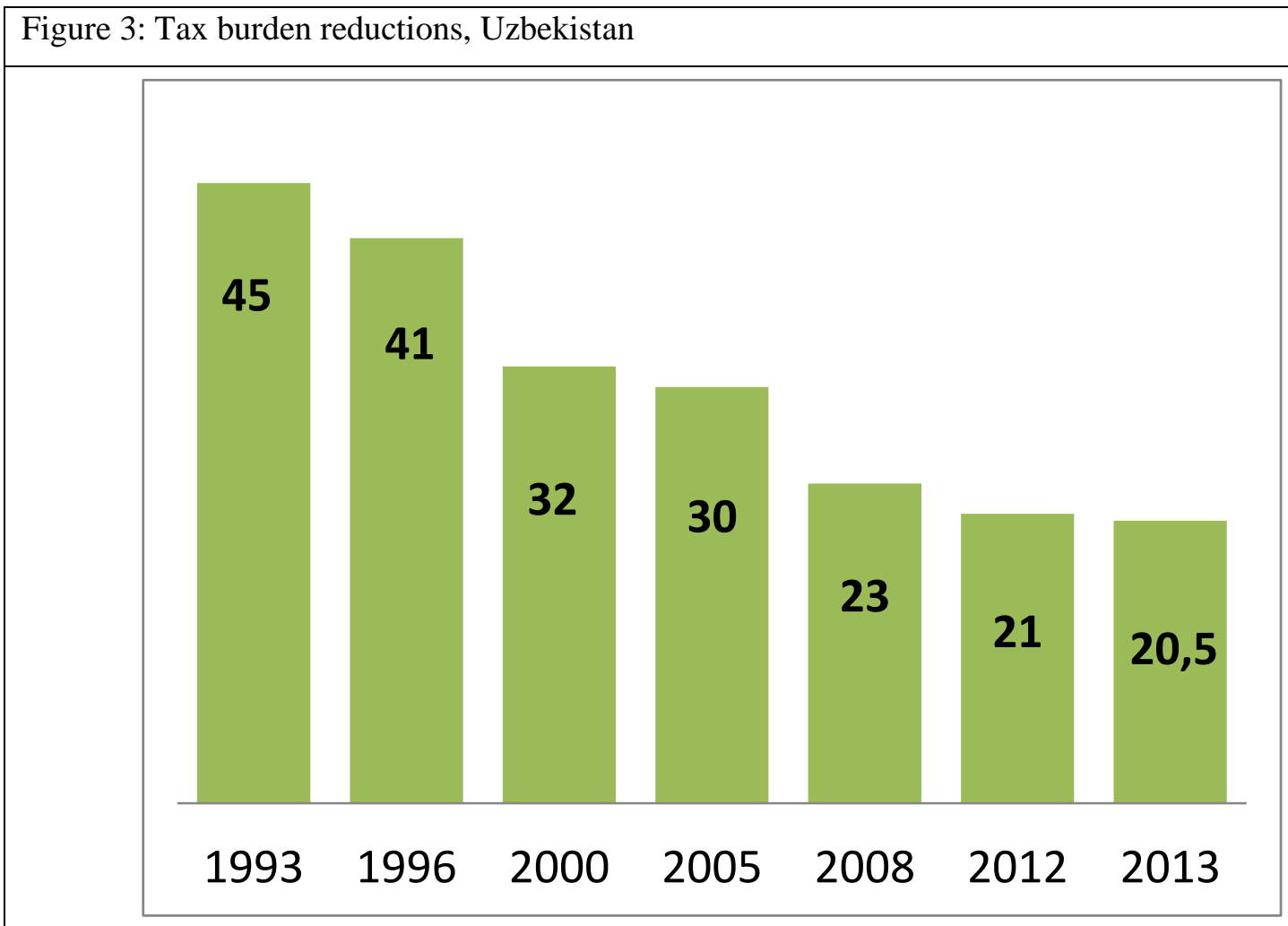

Source: Embassy of Uzbekistan (2014)

According to the Ministry for Foreign Economic Relations, Investments and Trade of the Republic of Uzbekistan (MERFIT, 2014), the income tax for enterprises with foreign investments is $16 \%$ (whereas the general rate is $20 \%$ ). This applies to the production enterprises with foreign investments where the foreign investments' share in the charter capital constitutes a minimum of $50 \%$, or equivalent to US\$1 million. Moreover, the enterprises with foreign investments specializing in some areas (for instance, production of children's footwear) are exempt from payment of VAT on imported raw materials. In addition, production enterprises with foreign investments are exempt from payment of land tax for the period of 2 years from the moment of their state registration. In addition, enterprises attracting direct private foreign investments are exempt from July 1, 2005, from payment on principal activity of income (profit) tax, property tax, tax on development of social infrastructure and improvement of territories, unified tax for micro-firms and small enterprises, as well as obligatory 
deductions to the Republican Highways' Fund. These tax privileges apply for three years if the direct private foreign investments constitute US\$0.3-3 million, for five years if these investments are US\$310 million, and for seven years if they are over US\$10 million. There are additional tax privileges for oil and gas exploring companies (MERFIT, 2014).

Gaybullaev (2011) tested the effectiveness of different types of tax privileges, both for foreign and local investors, based on 805 enterprises. The results showed that despite the high levels of investment, the depreciation of fixed assets in the machine industry was still quite high $(60.5 \%)$. Coefficients were calculated to measure the effectiveness of the incentives in surveyed companies. Based on the survey, the coefficients were less than one across all respondents (indicating that the growth in incentives outpaced growth in revenues). The results suggest that these incentives were only marginally efficient.

The elasticity coefficients supported these results, with figures of $0.27-0.29$ relating to the amount of revenue and tax benefits for large companies, and 0.53 for small enterprises.

Table 2: Elasticity coefficients indicate

\begin{tabular}{|l|r|r|r|r|}
\hline \multirow{3}{*}{ Sectors } & \multicolumn{2}{c|}{$\begin{array}{c}\text { Economic efficiency } \\
\text { (by revenues) }\end{array}$} & \multicolumn{2}{c|}{$\begin{array}{c}\text { Social efficiency } \\
\text { (by employee salaries) }\end{array}$} \\
\cline { 2 - 6 } & 2010 & 2011 & 2010 & 2011 \\
\hline Industry & 1.9 & 0.3 & 2.1 & 0.4 \\
\hline Transport & 0.6 & 0.8 & 0.6 & 1.0 \\
\hline Communication & 1.6 & 0.9 & 1.5 & 0.8 \\
\hline Constaruction & 0.4 & 15.9 & 0.6 & 0.8 \\
\hline All sectors & 0.9 & 0.7 & 0.9 & 11.4 \\
\hline
\end{tabular}

Source: Calculations based on data from the Tax Committee of Uzbekistan.

Note: if the ratio is greater than 1, the incentives are effective; if less than 1, they are not effective; if equal to 1 , they are neutral.

Unconditional and irrevocable tax and customs exemptions are the main reasons for the low efficiency of the incentives. The recipients of benefits do not have to demonstrate that production improved, in either quality or volume, or that it led to increased exports.

According to Gaybullaev (2011), companies have not demonstrated a strong demand for tax incentives. For instance, in 2010, only 66 companies took advantage of income tax breaks. This equals $0.5 \%$ of all corporate taxpayers. The study argues that many firms are granted full tax exemption, and thus many enterprises do not need the tax incentives.

The additional tax incentives introduced in 2013, mainly for exporters, small business enterprises, and companies, apply to new investments and production of new goods and products.

\section{Conclusion}

This paper describes capital inflows into the selected CIS countries and their investment climate. The study results show that private capital inflows into these countries consist mainly of direct investments, and concentrate in the few countries with big oil reserves. According to the results of the study, cumulative net FDI inflows per capita in the CIS countries are less than capital inflows received by the CEB countries ${ }^{5}$. A weak investment climate in the CIS, particularly from incomplete structural

\footnotetext{
${ }^{5}$ This refers to Central and Eastern Europe and the Baltic States.
} 
reforms, is the main reason for this phenomenon. This is despite strengthening macroeconomic performance. In addition, a lack of protection for property rights, with threats from corruption, crime, and excessive regulation, was the significant investment impediment cited most frequently in the research.

Tax incentives in the CIS countries consist of the organizing of Special Economic Zones, tax holidays, and sectorial tax privileges. Customs Union, launched in 2010, and the Common Economic Space of 2012, with aims of eliminating customs duties and harmonizing VAT, provide the fundamental freedoms to participant country investors.

According to a tax incentives strategy, the tax burden, as a total of the tax revenues, has been falling as a share of GDP. The analysis showed taxes fell from 26.2\% of GDP in 2000 to $21.5 \%$ in 2008, and then to an estimated $20.3 \%$ in 2013 . These reductions were compensated by rising indirect tax rates (such as taxes on property, water use, royalties on mineral deposits, consumption of gasoline and alcohol, excises on some imported foodstuffs, and the like). The Aggregate Tax Burden decreased by almost three times.

The tax incentives in Uzbekistan for foreign investors include income tax deductions, exemptions of VAT, organization of SEZ, and tax holidays. These apply for three years if the direct private foreign investments constitute US\$0.3-3 million, for five years if these investments are US\$3-10 million, and for seven years if they are over US\$10 million.

The effectiveness of these fiscal measures was tested using 805 enterprises, and according to the results, these incentives are only marginally efficient.

From our documented research, to improve the efficiency of tax privileges, we recommend linking tax incentives with results, exempting local equipment producers from the value-added tax, and stimulating either selected branches of the economy or the production of selected goods, rather than providing tax incentives for selected companies. We purport that a fiscal stimulus will not achieve the desired results without effective monetary, exchange-rate, and industrial policies, and importantly, more effective government institutions.

In summary, we submit that a strategy of increasing labor productivity, coupled with competitive labor cost, will increase efficiency-seeking FDI in the CIS countries.

\section{References}

Balco, T. (2013). Tax Incentives in Russia, Kazakhstan and Central Asia. KIMEP University. Central Asian Tax Research Center. Retrieved http://www.ibdt.com.br/material/arquivos/Palestras/Tomas\%20Balco.pdf

Borensztein, E., De Gregorio, J., \& Lee, J-W. (1998). How Does Foreign Direct Investment Affect Economic Growth? Journal of International Economics, 45(1), 115-35.

Broadman, H. G. (2002). Unleashing Russia's Business Potential: Lessons from the Regions for Building Market Institutions, Washington, DC: World Bank. Retrieved from https://openknowledge.worldbank.org/handle/10986/14096

Colin, J. (1998). State Keeps a Tight Rein: Market Reform in Uzbekistan. The Banker, 14(8), 47-50.

De Broeck, M., \& Koen, V. (2000). The Great Contractions in Russia, the Baltics, and the Other Countries of the Former Soviet Union: A View from the Supply Side. Working Paper No. WP/00/32. Washington: IMF.

Elborgh-Woytek, K., \& Lewis, M. (2002). Privatization in Ukraine: Challenges os Assessment and Coverage in Fund Conditionality. IMF Polisy discussion paper. Retrieved from https://books.google.ru/books?id=1zcG7DbULV4C \&pg=PP4\&lpg=PP4\&dq=Elborgh\%E2\%80\%93Woytek+and+Lewis+\%282002\%29\&source

Embassy of Uzbekistan in Belgium, Missions to EU. (2014). http://www.uzbekistan.be

Gaybullaev, O. (2011). Fiscal incentives in Uzbekistan: Have they worked? Retrieved from http://www.undp.org/content/ rbec/en/home/ourwork/povertyreduction/successstories/fiscal-incentives-in-uzbekistan--have-they-worked-.html

IMF. (2014, November 4). Замедление роста в РФ скажется на странах ЦА-МВФ [Slowing down of Russian growth will affect to the countries of Central Asia-IMF]. Retrieved from www.gazeta.uz/2014/11/04/imf/ 
Lankes, H-P., \& Venables, A. J. (1996). Foreign Direct Investment in Economic Transition: the Changing Pattern of Investments. Economics of Transition, 4(2), 331-347.

Ministry for Foreign Economic Relations, Investments and Trade of the Republic of Uzbekistan. (2014). Retrieved from www.mfer.uz/en/

Owen, D., and Robinson, D. O. (2003). Russia rebounds. Washington: IMF.

Peimani, H. (2009). Conflict and security in central Asia and Caucasus. Santa Barbara, California: ABC-CLIO.

Tsamenyi, M., \& Tauringana, V. (2004). Capital budgeting and budgeting practices of foreign operations in Uzbekistan: an exploratory study. International Journal of Strategic Cost Management. (Spring), 20-36.

Shiells, C. R. (2003). FDI and the Investment Climate in the CIS Countries. IMF Policy Discussion Paper. (November). Retrieved from www.imf.org

World Bank Group, (2014, October). World Bank Group - Uzbekistan partnership: country program snapshot. Retrieved from http://www.worldbank.org/content/dam/Worldbank/document/Uzbekistan-Snapshot.pdf

Vandycke, N. (2003). Economic Development and Private Sector Growth in the Low-Income CIS-7 Countries, Paper prepared for the Lucerne Conference of the CIS-7 Initiative, Retrieced from http://www.cis7.org 